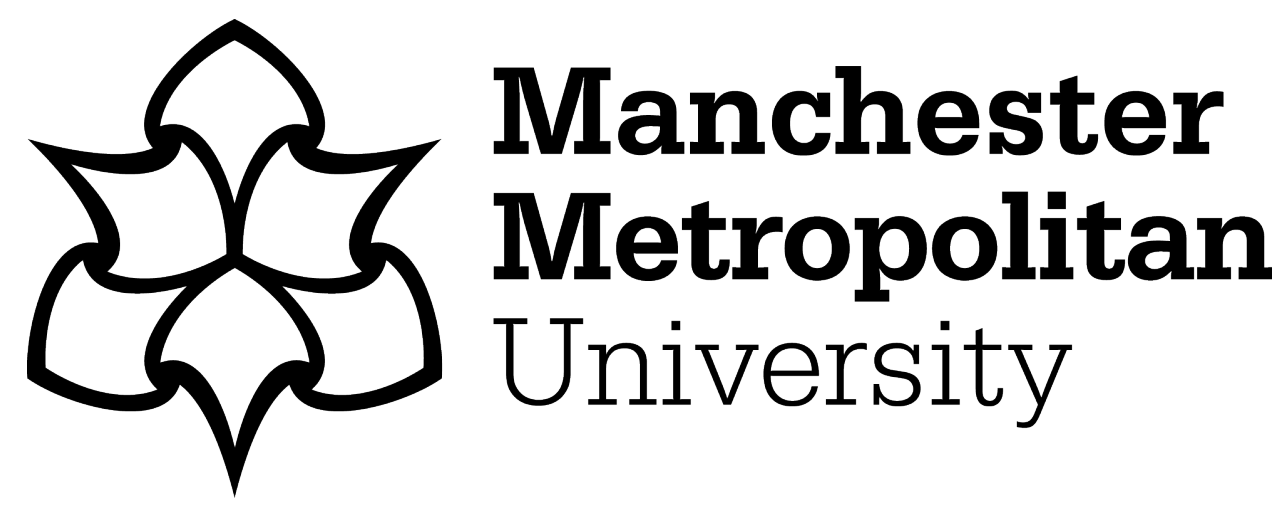

Cao, Qi ORCID logoORCID: https://orcid.org/0000-0001-5928-8422, Freund, David, Lee, Robert and Tuselmann, Heinz ORCID logoORCID: https://orcid.org/0000-0001-6628-1675 (2020) International high-tech SMEs innovative foreign knowledge inflows: effects of host country weak network ties and absorptive capacity. Multinational Business Review, 28 (3). pp. 333354. ISSN 1525-383X

Downloaded from: https://e-space.mmu.ac.uk/625922/

Version: Accepted Version

Publisher: Emerald

DOI: https://doi.org/10.1108/MBR-04-2019-0031

Please cite the published version 


\title{
International high-tech SMEs innovative foreign knowledge inflows: effects of host country weak network ties and absorptive capacity
}

\begin{abstract}
Purpose: The main purpose of this study is to explain the combined effects of host country weak network ties and absorptive capacity on the innovative foreign knowledge inflows of international high-tech SMEs.
\end{abstract}

Design/methodology/approach: Data are drawn from the two largest and most authoritative German Federal Government census-databases of biotech and nanotech SMEs. A structured survey questionnaire was administered and regression analysis adopted.

Findings: This study demonstrates weak network ties in the host country and developing absorptive capacity produces a combined effect that positively influences international hightech SMEs innovative foreign knowledge inflows. Also, host country weak network ties and absorptive capacity when considered separately, each respectively, positively influence innovative foreign knowledge inflows.

Practical implications: The results help inform key personnel in international high-tech SMEs about the relevance of host country weak network ties and absorptive capacity for foreign knowledge inflows. In addition, the results help policymakers and think-tanks to promote tailored advice and guidance e.g. those policymakers implementing the EU Entrepreneurship 2020 Action Plan.

Originality/value: There is a recent call in the literature to combine network theory and absorptive capacity theory to better explain knowledge creation in the context of international high-tech SMEs knowledge sourcing. By addressing this call, our study provides a more refined and comprehensive account of international high-tech SMEs innovative foreign knowledge inflows.

Keywords: SMEs High-tech Internationalisation Foreign Knowledge Networks Absorptive Capacity

\section{INTRODUCTION}

In the knowledge-driven and global economy, Small and medium-sized enterprises (SMEs) internationalising technology products are a driver of economic growth, continually innovate and attract talented employees (Autio and Ranniko, 2016; Shane, 2009; Yli-Renko et al, 2002). That said, international high-tech SMEs often suffer from the liabilities of smallness and competitive pressures (Crick and Jones, 2000; Filatotchev et al, 2011; Jones, 2001). This is because they lack critical resources and the operational capabilities and market power 
enjoyed by large technology multinationals (Lindstrand et al, 2011; Oehme and Bort, 2015; Reuber et al, 2017). Relentlessly pursuing external foreign market knowledge inflows that are innovative enable international high-tech SMEs to be creative and overcome the liabilities of smallness and resource constraints (Jones et al, 2011; Reuber and Fischer, 2011). Both Fletcher and Harris (2012) and Gassman and Keupp (2007) stress that the knowledge-base is a core competence of SMEs internationalising technology products, and by implication, increases international performance. While there is ample evidence pertaining to the positive influence of foreign knowledge on the entry mode choice and performance of international high-tech SMEs, this study seeks to explain the knowledge implications of establishing external networks and internally developing absorptive capacity. Though absorptive capacity positively influences the entrepreneurial internationalisation process, as suggested by Laufs and Schwens (2014), it is seldom combined with other theories such as network theory to more fully explain innovative knowledge and value creation in the context of international high-tech SMEs.

The role and importance of networks of weak ties in the host country for international high-tech SMEs foreign knowledge sourcing is well established in the literature (Lindstrand et al, 2011; Prashantham, 2015; Presutti et al, 2007). However, scholarly work concentrating on the beneficial effects of weak ties on high-tech SMEs internationalisation, in isolation, suggests an incomplete and partial picture (Ibeh et al, 2019; McDougall-Covin et al, 2014; Prashantham and Young, 2011). The concept of absorptive capacity refers to a value-added internal process whereby a firm recognises the importance of acquiring, assimilating and understanding new external knowledge, then, applying it to commercial ends (Cohen and Levinthal, 1990; Corredoira and Rosenkopf, 2010). In international entrepreneurship, most research focuses on the relationship between absorptive capacity and entry mode choice, internationalisation performance, learning or early internationalisation (e.g. Castro and Cepeda, 2016; Domurath and Patzelt, 2016; Fletcher, 2009; Raymond et al, 2015; Villar et al, 2014). According to Laufs 
and Schwens (2014:1124), the role and importance of absorptive capacity in international entrepreneurship is an 'open question' and under-researched. For Ferreras-Mendez et al (2019:432), there should be a shift towards explaining the combined effects of external networking and internal absorptive capacity capabilities on different 'types of knowledge', and whether this process might figure prominently in the success of international SMEs with a high degree of innovation orientation and technology development.

To advance an understanding of international high-tech SMEs innovative foreign knowledge inflows, we address several pertinent research questions. We acknowledge the central importance of weak network ties in the internationalisation process of high-tech SMEs and knowledge sourcing. That said, our research contributes a nuanced analysis by considering, separately, effects of different weak ties in the host country on valuable foreign knowledge inflows. So, what are the effects of different host country weak ties on international high-tech SMEs innovative foreign knowledge inflows? Some emerging research suggests absorptive capacity is increasingly important for SMEs export intensity and more rapid and early internationalisation. We also contribute to the literature by considering, separately, effects of absorptive capacity on the knowledge-base of SMEs internationalising sophisticated technology products. This implies the importance of the following question: what are the effects of absorptive capacity on international high-tech SMEs innovative foreign knowledge inflows? Additionally, there is a large research gap with regards what happens to international high-tech SMEs innovative foreign knowledge inflows when host country weak ties and absorptive capacity are combined. Combining network theory and absorptive capacity theory contributes novel findings and concerns the following question: what are the combined effects of host country weak ties and absorptive capacity investments on international high-tech SMEs innovative foreign knowledge inflows? 
As regards our sample and data, we derive highly relevant data from two timely and comprehensive German Federal databases of high-tech SMEs. Relatedly, German SMEs are top performers in the EU and globally in terms of international innovation, and therefore, a highly appropriate context to study the knowledge-base (Audretsch et al, 2018; EC, 2014a, 2014b; EC SBA, 2016; Federal Ministry of Education and Research, 2014). In the case of hightech SMEs internationalising technology products, their innovation and jobs creation potential are exceptional and an important focus of policy makers and think-tanks (Brown and Mawson, 2013; OECD, 2015). As such, our study of German international high-tech SMEs leveraging value from external networks and absorptive capacity routines is particularly relevant for EU policymakers implementing the flagship EU Entrepreneurship 2020 Action Plan. Indeed, the Action Plan is a response to the global financial crisis in 2008 and endeavours to harness the resilience of entrepreneurial firms that are increasingly growth focussed and innovation driven (EC, 2013). The flagship initiative - EU Entrepreneurship 2020 Action Plan - signposts a need to provide high-potential SMEs that internationalise value-added technologies across borders with more tailored and customised advice based on good practice and evidence from 'all over Europe' (EC, 2013:27). Thus, this paper offers some guidance for EU policymakers implementing recommendations in the Action Plan that assist the knowledge-base of international high-tech SMEs.

Next we review relevant literature pertaining to international high-tech SMEs innovative foreign knowledge, weaker ties and absorptive capacity. After this, we explain our survey approach, sample and quantitative analytical steps. We then present robust regression results and discuss our research contribution. Finally, we identify limitations, future research avenues and managerial-policy implications. 


\section{THEORY AND LITERATURE}

Our theoretical framework is multidisciplinary and consists of the knowledge-based view of high-tech SME internationalisation, emphasising particularly the importance of potent innovative foreign knowledge inflows. We also combine network theory and absorptive capacity theory to suggest that innovative foreign knowledge is an outcome of the international high-tech SME establishing external weak network ties in the host country, and at the same time, internally developing absorptive capacity capabilities. In this vein, we begin with a review of different types of knowledge beneficial for high-tech SMEs internationalising technological products, then, focus on how geographical proximity promotes social interaction and networks of weak ties as well as address absorptive capacity routines.

\section{Foreign Knowledge}

According to Nonaka and Takeuchi (1995), knowledge can reflect transferable and clearly articulated-codified facts (explicit) or intuitive insights, thoughts and experiential learning embedded in the human mind (tacit). In international entrepreneurship, foreign knowledge is strategically important and allows entrepreneurial firms to innovate and internationalise with greater efficiency (Schwens et al, 2018; Stoian et al, 2019). Pervasive codified knowledge typically involves the international high-tech SME establishing organisational structures and codification schemas to learn from 'direct' experience of entry mode choice, country selection and technology development (Casson, 2014; Evers and O'Gorman, 2011; Fletcher and Harris, 2012; Zahra et al, 2009). However, it is external sources of foreign knowledge accessed from vicarious tacit experiences such as 'indirect learning and grafting, and external sources of information' that can be transformed by the international hightech SME to continually innovate (Sandberg, 2014:22). Learning by doing and acquiring valuable tacit foreign knowledge-especially, market and technology specific knowledge is 
indispensable in the high-tech international entrepreneurship process (Cantwell, 2017; Casillas et al, 2009; Kollmann et al, 2016). Foreign technological knowledge facilitates international high-tech SMEs research and development (Crick and Crick, 2014; Prashantham and Young, 2011), and increases strategic agility, cultural awareness and sales performance (Crick and Jones, 2000; Crick and Spence, 2005; Zahra et al, 2009). Moreover, new foreign knowledge about demand, equipment, accreditation and regulation is a way for high-potential SMEs internationalising technology products to signal their market credibility and legitimacy to potential venture capitalist investors (Fernhaber et al, 2009; Park et al, 2015; Reuber and Fischer, 2011).

It is increasingly acknowledged that the knowledge-base of the international high-tech SME is a performance indicator itself (Alegre et al, 2013; Prashantham and Young, 2011; Saarenketo et al, 2008). The quality of tacit knowledge accrued from indirect learning experiences abroad is considered most crucial and valuable in the international innovation process of high-tech SMEs, and facilitates both the development of new radical products and refinement of existing products (DeClercq and Zhou, 2014; Li et al, 2011; Yli-Renko et al, 2002). Additionally, international high-tech SMEs are considered high potential and new foreign knowledge that is additive and innovative enables more rapid internationalisation (Cavusgil and Knight, 2015; Deligianni et al, 2015; Garcia-Garcia et al, 2017; Nordman and Melen, 2008; Zander et al, 2015). The rapid speed view of high-tech SME internationalisation contrasts SME internationalisation understood as a long-term process of expansion and increased foreign commitment based on incremental steps and risk reduction (Coviello and McAuley, 1999; Verbeke et al, 2014; Wright et al, 2007). So, tacit foreign knowledge that is innovative and additive makes it possible for international high-tech SMEs to maximise the potential of new radical-premium technological products to be internationalised and increase 
speed of internationalisation (Gassman and Keup, 2007; Fletcher and Harris, 2012; Hanell et al, 2018; Marcone, 2012).

\section{Networks and weak ties}

Inspired by Granovetter's (1973) social embeddedness argument, a great deal of technology entrepreneurship research suggests that social network exchanges external to the firm are predicated on social norms and facilitate resource sharing (Florin et al, 2003; Lee et al, 2001; Liebeskind et al, 1996; Maurer and Ebers, 2006). An additional consideration is network structural diversity - densely connected networks of strong ties involve repeated interaction with similar others and fair exchange - while low-density networks comprising many socially distant weak ties are more heterogeneous and information rich (Coviello, 2006). In the case of international high-tech SMEs, weak social exchanges are crucial and often take place between individuals or firms across borders and global value chains (Coviello and Munro, 1995; Presutti et al, 2007; Schwens and Kabst, 2010). Information rich weak foreign ties also facilitate self-efficacious opportunity identification and non-redundancy benefits for SMEs internationalising technological products (Ellis, 2011; Lindstrand et al, 2011; Lindstrand and Hanell, 2017).

Related to this, geographic proximity to collaborators is an important proxy of the possibilities to establish valuable and divergent weak ties abroad and access new knowledge (Döring and Schnellenbach, 2006; Lazzeretti and Capone, 2016). For Corredoira and Rosenkopf (2010:162), 'geographic proximity is likely to proxy for a host of mechanisms that may facilitate knowledge', specifically, weak network ties. Indeed, geographic proximity promotes serendipitous meetings and beneficial unintended interdependencies (Bathelt et al, 2004; Mattes, 2012; Storper, 1997). As such, geographic proximity to external organisations and institutions such as innovative firms, suppliers and universities in the host country 
represents abundant opportunities for international high-tech SMEs to establish information rich weaker network ties and accrue divergent knowledge (Buckley and Prashantham, 2016; Davenport, 2005).

Innovative firms. Geographic proximity to innovative competitors, customers and specialist consortia abroad implies opportunities for international high-tech SMEs to create beneficial interdependencies (Presutti et al, 2007, 2016). Socialisation with accomplished and reputable firms promotes the development of common perceptions and vocabularies, which are preconditions for the transfer of highly valuable technical and market knowledge (Boschma, 2005). Also, this socialisation with other business players ensures that international high-tech SMEs accurately interpret complex technical and market knowledge (Lindstrand and Hånell, 2017; Prashantham, 2015). Furthermore, the establishment of weak ties with innovative firms in the host country can be especially useful when the international high-tech SME diversifies and requires timely information about customer trends and regulation (Kuivalainen et al, 2012; Presutti et al, 2016; Zimmerman et al, 2011). According to Jonsson and Lindbergh's (2010:558) study pertaining to knowledge-intensive international SMEs, 'knowledge obtained from international business partners helps firms make relationship specific investments, which, in turn, improves performance'. As such, interaction and knowledge sharing with other firms and abroad permits the mutual sharing of information with regards some internationalisation aspects and competition on others (Etemad, 2016; Lindstrand et al, 2011; Reuber and Fischer, 2011).

Innovative suppliers. Geographic proximity to innovative suppliers abroad provides opportunities for international high-tech SMEs to strengthen their position in increasingly supplier-driven international innovation networks (Jean et al, 2016; Ojala, 2009). International high-tech SMEs' geographic proximity to innovative suppliers abroad facilitates competitive advantages such as access to high-quality and timely scientific equipment and materials (Kang 
et al, 2009; Lindstrand et al, 2011). Additionally, identifying interactive opportunities with suppliers, buyers and distributors enables international high-tech SMEs to access valuable foreign knowledge and continuous updates (Coviello and Munro, 1995; Fernhaber et al, 2009; Fletcher and Harris, 2012; Ojala, 2009). Indeed, Lindstrand et al (2011) suggest that SMEs internationalising complex technological products must meet sales-delivery targets and more focussed vertical networking with suppliers ensures a collaborative state of strategy formulation. This focussed networking behaviour with suppliers and international distributors, in turn, enables more resource constrained SMEs internationalising technology products to increase the speed of innovation and better mitigate salient market challenges and competitive pressures (Etemad, 2016; Henke and Zhang, 2010; Partanen et al, 2008).

Universities and scientific institutions. In the knowledge-driven economy, universities and scientific institutions are crucial sources of new and previously unknown knowledge (Acs et al, 2013; Autio and Ranniko, 2016; Kollman et al, 2016). Geographic proximity to publicprivate research institutions has been shown to be particularly relevant for SMEs internationalising technology products (Chai and Shih, 2016; Prashantham, 2015). Also, geographic proximity to universities and scientific institutions in technology frontier regions exposes international high-tech SMEs to new scientific and technological advancements (Audretsch et al, 2011). For instance, Eerme and Nummela (2019) demonstrate that international high-tech SMEs establishing weak ties with specialist institutions and big science centres access open data and non-linear and emergent scientific knowledge. Furthermore, universities and scientific institutions can provide SMEs internationalising technology products with valuable ad-hoc training and technical advice (Audretsch et al, 2014; Halilem et al, 2012). 


\section{Absorptive capacity}

In their seminal study, Cohen and Levinthal (1990) posit that absorptive capacity refers to a firm's ability to recognise the importance of acquiring, understanding and assimilating new externally sourced knowledge. Absorptive capacity underpins innovation activities and provides opportunities for an organisation to transform knowledge and foster continuous change and strategic renewal (Lane and Lubatkin, 1998; Lane et al, 2006; Volberda et al, 2010; Zahra and George, 2002). In particular, research intensive firms with productive external networks tend to develop a broader knowledge-base and use absorptive capacity routines to understand newly acquired knowledge and generate new patents and products (Kim et al, 2016; Patterson and Ambrosini, 2015; Roberts et al, 2012). Research and development staff, intrapreneurs and corporate venturing teams are motivated to transform new knowledge (Corredoira and Rosenkopf, 2010; Garcia-Morales et al, 2014). While alliance partners willing to invest in research and development activities can more effectively learn from each other and better leverage the alliance resources (Srivastava et al, 2015). With regards multinational corporations, experiential learning and the development of absorptive capacity facilitates knowledge flows between headquarters and subsidiaries and identification of new customers (Eriksson and Chetty, 2003; Mahnke et al, 2005).

Knowledge absorption routines and learning enable international SMEs to intensify the search and exploitation of new foreign opportunities (DeClercq et al, 2012; Dimitratos et al, 2014; Ibeh et al, 2019; Zerwas, 2014). Absorptive capacity provides international SMEs with the ability to learn and adapt in foreign markets, mitigate environmental uncertainty and increase sales (Castro and Cepeda, 2016; Raymond et al, 2015; Zhu et al, 2006). In particular, learning and knowledge absorption routines, including acquiring and understanding knowledge, are beneficial for SMEs internationalising rapidly and early (Domurath and Patzelt, 2016; Fletcher, 2009; Prashantham and Young, 2011), and with an export strategy (Ferreras- 
Mendez et al, 2019). A pertinent study by Villar et al (2014) demonstrates that knowledge management practices constitute a competitive advantage in low-tech SMEs and influence export intensity. The nature of absorptive capacity in the internationalisation process of hightech SMEs is seldom studied, that said, the absorptive capacity routines of acquiring and understanding knowledge is essential for the commercialisation activities of new high-tech ventures and start-ups supported by incubators or science parks (Filatotchev et al, 2011; Flor et al, 2018; Patton, 2014; Saemundsson and Candi, 2017). High-tech start-ups invest a great deal of time innovating and absorptive capacity enhances commercialisation (Limaj and Bernroider, 2019; Xia and Roper, 2016). Since it is important for international high-tech SMEs to respond to opportunities in rapidly changing global markets, we suggest that their absorptive capacity is crucial for innovative knowledge inflows and international innovation.

\section{METHOD}

\section{Sample, survey and respondents}

International nanotech and biotech SMEs are a highly appropriate context to study innovative foreign knowledge inflows, because they rely heavily on external knowledge to continually innovate new products, respond to demand and sustain competitive advantage ( $\mathrm{Li}$ et al, 2011; Lindstrand et al, 2011; Nordman and Melen, 2008; Oehme and Bort, 2015). Here, it should also be stressed that German SMEs are top performers in terms of internationalisation, technology development and innovation, this further suggests an appropriate context for a sample to be drawn (Audretsch et al, 2018; EC, 2014a, 2014b; EC SBA, 2016; Federal Ministry of Education and Research, 2014). Therefore, we developed a bespoke and tailored database from the largest and most authoritative German nanotech (842 SMEs) and biotech (391 SMEs) census-databases provided by the German government. ${ }^{1}$ Based on extensive website-searches

\footnotetext{
${ }^{1}$ https://www.werkstofftechnologien.de/en/service/nano-map\#/?se=u27uzmqc2yde
} 
of each firm, we excluded non-relevant firms (such as sole wholesalers, specialised law firms etc.), which led to the final sample size of 885 biotech and nanotech SMEs.

We applied a survey design and collected robust data through a structured email questionnaire. Reminder waves were sent to the managing director of the 885 SMEs. We received 204 responses, which equals an effective response rate of $23 \%$ and compares well with similar studies in the field (Hollender et al., 2017; Schwens et al., 2011). In line with various related studies (Brouthers, 2013; Oehme and Bort, 2015; Yip et al., 2000), we focus on substantive internationalisation activities and exclude export observations and SMEs only operating domestically, which led to 144 usable questionnaires for our analysis. Of those, 66.7\% were nanotech SMEs and 33.3\% were biotech SMEs. We conducted tests for nonresponse bias comparing respondents' industry and location with the total population of the combined German Ministry databases and did not find any significant differences. We used wave analysis to test for differences between early and late respondents on firm size, age, industry and location. No significant differences were found.

\section{Variables and measurement}

In order to obtain a high degree of content and face validity, the questionnaire constructs and items were underpinned by scholarly theory. Pertaining to questionnaire design and layout, we consulted with a practitioner panel comprising industry and academic experts. Moreover, we piloted the questionnaire with a selection of the target audience to scrutinise and inform the final version and inclusion of variables. The dependent variable captures innovative foreign knowledge inflows, namely-the extent of additive and value-added foreign knowledge inflows to the SME. Respondents were asked to express their agreement on a seven-point Likert scale to the statement 'The knowledge sourced abroad is important for the development of our

http://biotechnologie.de/profiles 
products and patents'. We transformed the scores by adopting a binary classification scheme based on Arvanitis and Hollenstein's (2011) transformation procedures to achieve a higher variability and to balance out issues related to the minimum sufficiency requirements for number of observations in each scale (Hair et al, 2006). Respondents with a score between 14 are allocated the value of 0 and reflect SMEs with lower innovative knowledge inflows. The value 1 was allocated to respondents with a score between 5-7 and represents SMEs with higher innovative knowledge inflows.

To proxy weak and informal network ties in the host country, we employed three variables with single measurement items adapted from various studies (i.e. Ambos, 2005; Davis and Meyer, 2004). First, the geographic proximity to innovative firms variable captures the SME's opportunity to participate in divergent social and economic spheres. Second, the geographic proximity to innovative suppliers variable accounts for the opportunity to strengthen transactional advantages in increasingly supplier-driven international innovation networks. Third, the geographic proximity to universities \& scientific institutions variable accounts for exposure to new developments in the field, technical support and socio-cultural preconditions for learning. For all three weak network ties variables, respondents were asked to indicate the importance of proximity to each network partner abroad on a seven-point Likert scale.

To measure absorptive capacity and capture the knowledge absorption capabilities of the SME, we adopted Mahnke et al's (2005) measurement construct. Respondents were asked to express their agreement on a seven-point Likert scale to the statements 'We can easily acquire the knowledge accessed abroad' and 'We perfectly understand the knowledge accessed abroad'. The construct is internally consistent with a Cronbach's $\alpha$ of .815 . 
As regards other firm and industry characteristics that might influence innovative knowledge inflows, we include firm age, firm size and industry as controls. Table 1 outlines the extant variables, measurement and conceptual background.

----- Insert Table 1 here-----

To test for common method bias, we employed Lindell and Whitney's (2001) marker variable procedure by adding 'Ability to Achieve Scale Economies' as a marker variable, which is theoretically unrelated to the substantive variables under investigation. The delta standardized regression weights (SRW) were estimated by subtracting estimated SRW of the Marker Variable model from the original model. The largest delta standardized regression weights we observed is 0.005 , far below the benchmark of 0.2 . Moreover, we employed the expost Harman one factors test to detect common method variance (Podsakoff and Organ, 1986). The single construct's total percentage of variance in the principal axis factoring extraction and assigned rotation method (Conway and Lance, 2010$)$ is $17.77 \%$, indicating no severe $(>50 \%)$ variance from a single factor.

Although diagnostic tests indicate absence of common method bias, to ensure that there are no hidden constructs or unobserved factors influencing the results, we follow Lindell and Whitney's (2001) and Podsakoff et al's (2003) suggestion of creating latent common factors to estimate the unobserved variances among all variables. Based on the Common Latent Factor (CLF) model, unstandardised common method bias is at $4.41 \%$. The largest Delta SRW value is at 0.005 (industry, estimated SRW CLF -.0090, estimate SRW Original -0.085) and there is no regression Delta SRW value above 0.2. This indicates no variable or clusters are severely affected by common method bias in our model. 


\section{Analytical approach}

We investigated potential multicollinearity problems prior to running the regression estimations. The correlation matrix in Table 2 shows that all correlation coefficients are below the threshold of concern of 0.7 (Hair et al., 2006). The variance inflation factors (VIFs) range between 1.13 and 2.38 well below the critical threshold of 5.0 (Studenmund, 2001), confirming no underlying problems with multicollinearity. Post-estimation checks such as split sample technique and alteration of the control variables set confirmed the robustness of our results.

We adopted a fractional logit generalised linear (FLGLM) regression approach, because it addresses outlier problems in truncated datasets by employing non-linear dynamic regression. The link function compares estimations and computations with all alternative conventional regression types (such as probit regression, general linear model) - to evaluate if they are more efficient in predicting causality-causation (i.e. explanatory power) (Williams, 2016). Another advantage is that it corrects for possible heteroscedasticity related errors by generating latent functions in the regression analysis and identifies effects of unobserved heterogeneity (Wooldridge, 2010).

----- Insert Table 2 here-----

\section{RESULTS}

Table 3 presents the diagnostics and results of our FLGLM approach. The link tests indicate that our FLGLM approach is more efficient and superior when compared to alternative conventional regression types. Following Williams (2016), the Akaike information criterion (AIC) should be below ten and Bayesian information criterion (BIC) should be negative. The diagnostics in Table 3 show that for all our models the AIC range is between 1.213 to 1.318 and the BICs are constantly negative. 
Models I and II show effects of host country weak network ties and absorptive capacity, separately, on international high-tech SMEs innovative foreign knowledge. The results pertaining to models I and II show that host country networks consisting of weak ties with suppliers and other firms and absorptive capacity when considered separately, each respectively, positively influence innovative foreign knowledge inflows. Though weak ties with universities and scientific institutions in the host country was not a significant predictor of innovative foreign knowledge inflows. The separate effects of host country weak ties with innovative firms and suppliers is not surprising, in light of the previous research that documents the knowledge benefits of weak ties for international high-tech SMEs. More novel and pertinent is the separate effect of absorptive capacity, which indicates that international hightech SMEs investments in absorptive capacity routines contribute to innovative foreign knowledge inflows.

The main results are presented in the full model III. Taking together and simultaneously considering the host country weak ties and absorptive capacity, allows for a more refined and realistic examination of international high-tech SMEs' innovative foreign knowledge inflows, as argued in the theory and literature. Weak ties with innovative firms and suppliers in the host country significantly and positively predict innovative foreign knowledge inflows. However, innovative knowledge inflows are not predicted by weak ties with universities and scientific institutions in the host country. In this way, host country weak ties with innovative firms and suppliers when considered alongside absorptive capacity produce a combined effect and facilitate innovative foreign knowledge inflows. It is clear that the innovative foreign knowledge inflows of international high-tech SMEs are distinctively shaped by host country weak ties with innovative firms and suppliers, and at the same time, absorptive capacity investments. 


\section{DISCUSSION}

This research seeks to advance an understanding of the knowledge-based view of SMEs internationalising technology products (Fletcher and Harris, 2012; Gassman and Keupp, 2007; Yli-Renko et al, 2002). Since international high-tech SMEs operate in complex and high-risk global markets, we suggest that innovative foreign knowledge inflows are additive and most valuable. We treated innovative foreign knowledge inflows as the outcome of an external and internal value-creation process-namely, the combined and simultaneous effects of host country weak network ties and absorptive capacity routines. This answers recent calls to combine network theory and absorptive capacity theory to more fully account for the knowledge inflows in international SMEs with a high degree of innovation orientation (Ferreras-Mendez et al, 2019; Laufs and Schwens, 2014). We suggest that our data and results make several contributions.

First, we add to the network literature by showing, separately, effects of different host country weaker network ties on innovative foreign knowledge inflows in the international hightech SME. Much prior research shows that weak network ties in the host country are important sources of different types of foreign knowledge such as market and technical in the high-tech SME internationalisation process (Fletcher and Harris, 2012; Lindstrand et al, 2011; Ojala, 2009; Presutti et al, 2007). The results as regards effects of host country weak network ties, when considered separately, are consistent with this previous network scholarship and demonstrate such network activity provides knowledge gains. Though our results go beyond existing research and provide a nuanced view of the international high-tech SMEs knowledgebase, by explaining links between weak external networks that capture non-redundancy benefits, specifically, innovative knowledge inflows. As such, we demonstrate that weaker ties to suppliers and other firms in the host country are important sources of innovative knowledge inflows for SMEs internationalising technology products. However, weaker ties to host country 
universities show no effect. As regards this discrepancy, it is possible that the more institutionalised and formal nature of public universities makes opportunities for knowledge transfer less abundant. While weaker ties to innovative suppliers and other firms are likely to be more socially embedded and opportunities for social interaction and knowledge more abundant.

Second, the results add to the absorptive capacity literature by demonstrating, separately, effects of developing absorptive capacity on innovative foreign knowledge inflows in the international high-tech SME. Laufs and Schwens (2014) suggest that the role and importance of absorptive capacity in the entrepreneurial internationalisation process is an open question and studies are still emerging. In international entrepreneurship, emerging research tends to demonstrate the positive influence of absorptive capacity on increased export intensity and more rapid and early internationalisation (Domurath and Patzelt, 2016; Ferreras-Mendez et al, 2019; Villar et al, 2014). Our study, however, shows that absorptive capacity, when considered separately, positively impacts the innovative knowledge inflows of international high-tech SMEs. In general, then, this result supports emerging studies that suggest absorptive capacity is crucial for international SMEs with an export strategy or more early and rapid foreign entry. But we make a distinctive contribution and advance the current literature by showing how absorptive capacity, measured as acquisition and understanding, influences foreign knowledge inflows in the high-tech SME internationalisation process.

Third, our most intriguing contribution reflects answering Ferreras-Mendez et al's (2019) call to consider absorptive capacity alongside other theories in an integrative manner and better explain the internationalisation knowledge of SMEs with high innovation orientation. We intentionally combine network theory and absorptive capacity theory to explain their combined and simultaneous effects on international high-tech SMEs innovative foreign knowledge inflows. To this end, we demonstrate that international high-tech SME's capture 
significant external knowledge benefits when they identify new foreign knowledge, acquire and understand it, and apply it to commercial ends, while at the same time expanding networks and establishing host country weak ties. Network theory and absorptive capacity theory seem inextricably related to innovative knowledge and exhibit a combined effect. This seems particularly important for SMEs operating in fast moving high-tech industries to stay competitive (Filatotchev et al, 2011).

\section{POLICY IMPLICATIONS}

Turning to policy implications, a core policy aim in the flagship EU Entrepreneurship 2020 Action Plan is to 'foster the knowledge-base' of high-potential and technological SMEs (EC, 2013:14). Based on our novel findings pertaining to all nanotech and biotech SMEs in Germany, the preceding analysis and discussion suggest policymakers implementing the flagship Action Plan should tailor guidance and forms of support to better promote international high-tech SMEs host country networking and absorptive capacity routines. Different types of firms in the EU require appropriately adapted policy support and interventions implemented in an undifferentiated manner can be misleading (Brown and Mawson, 2013; EC, 2013; Miguelez and Moreno, 2015).

As regards networking, it is argued in the EU Action Plan that high-tech SMEs piloting and internationalising new technologies need more customised guidance about 'networks and other types of association' across global borders and changing business landscapes (EU, 2013:11). Indeed, the EU Action Plan acknowledges that networks 'provide valuable knowledge' (EC, 2013:9). To signpost tailored advice about access to new foreign knowledge via host country weak ties, EU policymakers should encourage international high-tech SMEs to network in the host country with potential suppliers and other innovative firms such as peers, clients and competitors. Targeted host country networking ensures efficient time investments 
for international high-tech SMEs and improves the ease and speed of their access to innovative foreign knowledge inflows. This very specific advice and guidance should be signposted to high-SMEs internationalising technology products by the Enterprise Europe Network and European Innovation Partnerships.

With regards absorptive capacity, the EU Action Plan argues that high-potential SMEs need to 'strengthen competencies... and entrepreneurial learning to address new technological markets' (EC, 2013:14). Absorptive capacity means acquiring and assimilating new knowledge, and perhaps more importantly, understanding its potential for commercialisation. Thus, instructors at the European Institute of Technology and Business Forum and Sector Skills agencies should provide guidance to international high-tech SMEs about absorptive capacity investments, particularly learning about the necessity to understand and assimilate new knowledge and its commercialisation potential.

\section{THEORETICAL IMPLICATIONS}

With respect to implications for theory, our study provides wider implications for International Entrepreneurship literature (Jones et al, 2011), particularly regarding the little explored effects of developing absorptive capacity (Ferreras-Mendez et al, 2019; Laufs and Schwens, 2014). Our empirical results lend support to the implication that studies concerned with conceptualising innovative foreign knowledge inflows should consider the role and importance of absorptive capacity, and its interplay with other intangibles assets (Ibeh et al, 2019). We contribute to this, being one of the first to model and empirically test an absorptive capacity combination with networks of weak network ties. We suggest much more research on how the high-tech international SME develops new competences is needed, leading us to suggest that the International Entrepreneurship field, gradually develop a refined understanding of multiple combinations of intangibles. 


\section{PRACTITIONER IMPLICATIONS}

The results also help to inform key decision-makers in international high-tech SMEs as regards innovative foreign knowledge inflows. In fact, international high-tech SME managers rely on an understanding to what extent proximity and knowledge management routines provide a valid, valuable and time efficient avenue for accessing and acquiring distant complementary knowledge abroad (Jones, 2001). In particular, the cultivation of absorptive capacity routines such as recognising the importance of acquiring and understand new knowledge should be promoted in the workforce. Moreover, weaker ties act as bridges to new contexts and the proactive establishment of host country weak ties with innovative firms and suppliers seems a valid strategy for accessing innovative foreign knowledge. Such proactive absorptive capacity investments and establishing weak ties in the host country could enable international high-tech SMEs to better overcome their resource constraints and liabilities of smallness.

\section{LIMITATIONS AND FUTURE RESEARCH}

Our empirical study suffers from the conventional limitations of cross-sectional research design. Also, it is only based on a single country (Germany) and two high-tech sectors (biotech, nanotech). Nevertheless, our study provides a comprehensive starting point for further research - both quantitative and qualitative - to examine additional samples of SMEs from other industries and other industrialised economies. Furthermore, future studies should dedicatedly address other types of proximity (e.g. institutional, organisational, cognitive) individually and combined. Related to this, future research may integrate and directly measure additional structural features of network ties abroad (e.g. network density, cohesion, centrality, structural holes) as well as absorptive capacity features (e.g. potential, realised). 


\section{REFERENCES}

Aalbers, R., Dolfsma, W. and Koppius, O. (2014), "Rich Ties and Innovative Knowledge Transfer within a firm”, British Journal of Management, Vol. 23, pp. 96-109.

Acs, Z.J., Audretsch, D.B. and Lehmann, E.E. (2013), "The knowledge spillover theory of entrepreneurship”, Small Business Economics, Vol. 41 No. 4, pp. 757-774.

Al-Aali, A., and Teece, D.J. (2014), "International Entrepreneurship and the Theory of the (Long-Lived) International Firm: A Capabilities Perspective", Entrepreneurship Theory and Practice, Vol. 38 No.1, pp. 95-116.

Alegre, J., Sengupta, K. and Lapiedra, R. (2013), "Knowledge management and innovation performance in a high-tech SME industry", International Small Business Journal, Vol. 31 No. 4, pp. 454-470.

Ambos, B. (2005), "Foreign direct investment in industrial research and development: A study of German MNCs", Research Policy, Vol. 34 No. 4, pp. 395-410.

Arvanitis, S. and Hollenstein, H. (2011), "How do different d rivers of R\&D investment in foreign locations affect domestic firm performance? An analysis based on Swiss panel micro data”, Industrial and Corporate Change, Vol. 20 No 2, pp. 605-640.

Audretsch, D.B. (1998), "Agglomeration and the location of innovative activity", Oxford Review of Economic Policy, Vol. 14 No. 2, pp. 18-29,

Autio E and Rannikko H (2016), "Retaining winners: Can policy boost high-growth entrepreneurship?” Research Policy Vol. 45 No. 1, pp. 42-55.

Audretsch, D., Aldridge, T. and Sanders, M. (2011) "Social capital building and new business formation: A case study in Silicon Valley", International Small Business Journal, Vol 29, pp. 152-169.

Audretsch, D., Lehmann, E. and Wright, M. (2014) "Technology transfer in a global economy", Journal of Technology Transfer, Vol 39 No. 3, pp. 301-312.

Audretsch, D., Lehman, E. and Schenkenhofer, J. (2018), "Internationalization strategies of hidden champions: lessons from Germany", Multinational Business Review, Vol 26 No. 1, pp $2-24$.

Bathelt, H., Malmberg, A. and Maskell, P. (2004), "Clusters and knowledge: local buzz, global pipelines and the process of knowledge creation", Progress in Human Geography, Vol. 28 No. 1, pp. 31-56.

Boschma, R. (2005), "Proximity and innovation: A critical assessment", Regional Studies, Vol. 39 No. 1, pp. 61-74.

Brown, R. and Mawson, S. (2013), "Trigger points and high-growth firms: A conceptualisation and review of public policy implications", Journal of Small Business and Enterprise Development, Vol. 20 No. 2, pp. 279-295. 
Bradley, F., Meyer, R. and Gao, Y. (2006), "Use of supplier-customer relationships by SMEs to enter foreign markets“, Industrial Marketing Management, Vol. 35 No. 6, pp. 652-665.

Brouthers, K.D. (2013), "Institutional, cultural and transaction cost influences on entry mode choice and performance“", Journal of International Business Studies, Vol. 44 No. 1, pp. 1-13.

Buckley PJ and Prashantham S (2016), "Global Interfirm Networks: The Division of Entrepreneurial Labor between MNEs and SMEs", Academy of Management Perspectives Vol 30 No. 1, pp. 40-58.

Cantwell, J. (2017), "Innovation and international business", Industry and Innovation, Vol. 24 No. 1, pp. 41-60.

Casillas, J., Moreno, A., Acedo, F., Gallego, M. and Ramos, E. (2009), “An integrative model of the role of knowledge in the internationalization process", International Business Review, Vol. 44 No. 3, pp. 311-322.

Casson, M. (2014), "The economic theory of the firm as a foundation for international business theory”, Multinational Business Review, Vol. 22 No. 3, pp. 205-226.

Castro, I. and Cepeda, G. (2016), "Social capital, absorptive capacity and entrepreneurial behaviour in an international context", European Journal of Innovation Management, Vol. 10 No. 4, pp. 479-495.

Cavusgil, T. and Knight, G. (2015), "The born global firm: An entrepreneurial and capabilities perspective on early and rapid internationalization", Journal of International Business Studies, Vol. 46 No. 1, pp. 3-16.

Chai, S. and Shih, W. (2016), "Bridging science and technology through academic-industry partnerships“, Research Policy, Vol. 45 No. 1, pp. 148-158.

Ciabuschi, F., Dellestrand, H. and Kappen, P. (2011), "Exploring the Effects of Vertical and Lateral Mechanisms in International Knowledge Transfer Projects“, Management International Review, Vol. 51 No. 2, pp. 129-155.

Cohen, W.M. and Levinthal, D.A. (1990), “Absorptive Capacity: A New Perspective on Learning and Innovation“, Administrative Science Quarterly, Vol. 35 No. 1, pp. 128-152.

Conway, J.M. and Lance, C.E. (2010), "What reviewers should expect from authors regarding common method bias in organizational research", Journal of Business and Psychology, Vol. 25 No. 3, pp. 325-334.

Corredoira, R. and Rosenkopf, L. (2010), "Should Auld Acquaintance Be Forgot? The Reverse Transfer Of Knowledge Through Mobility Ties", Strategic Management Journal, Vol. 31, pp. 159-181.

Coviello, N. and McAuley, A. (1999), "Internationalisation and the Smaller Firm: A Review of Contemporary Empirical Research", Management International Review, Vol. 39 No. 3, pp. 223-256. 
Coviello, N. and Munro, H. (1995), "Growing the Entrepreneurial Firm: Networking for International Market Development", European Journal of Marketing, Vol. 29 No. 7, pp. 4961.

Coviello, N. (2006), "The Network Dynamics of International New Ventures", Journal of International Business Studies, Vol. 37 No. 5, pp. 713-731.

Crick, D. and Jones, M. (2000), "Small High-Technology Firms and International HighTechnology Markets”, Journal of International Marketing, Vol. 8, No. 2, pp. 63-85.

Crick, D. and Spence, M. (2005), "The internationalisation of 'high-performing' UK high-tech SMEs: a study of planned and unplanned strategies", International Business Review, Vol. 14, No. 2, pp. 167-185.

Crick, D. and Crick, J. (2014), "The internationalization strategies of rapidly internationalizing high-tech UK SMEs”, European Business Review, Vol. 26 No. 5, pp. 421-448.

Davenport, S. (2005), "Exploring the role of proximity in SME knowledge-acquisition", Research Policy, Vol. 34 No. 5, pp. 683-701.

Davis, L.N. and Meyer, K.E. (2004), "Subsidiary research and development, and the local environment", International Business Review, Vol. 13 No. 3, 359-382.

De Clercq, D., Sapienza, H., Yavuz, R. and Zhou, L. (2012), "Learning and knowledge in early internationalization research: Past accomplishments and future directions", Journal of Business Venturing, Vol. 27No.1, pp. 143-165.

De Clercq, D. and Zhou, L. (2014), "Entrepreneurial Strategic Posture and Performance in Foreign Markets: The Critical Role of International Learning Effort", Journal of International Marketing, Vol. 22 No. 2, pp. 47-67.

Deligianni, I., Voudouris, I. and Lioukas, S. (2015), "Growth paths of small technology firms: The effects of different knowledge types over time", Journal of World Business, Vol. 50 No. 3, pp. 491-504.

Dimitratos, P., Amoros, J.E., Etchebarne, M.S. and Felzensztein, C. (2014), "Micromultinational or not? International entrepreneurship, networking and learning effects", Journal of Business Research, Vol. 67 No. 5, pp. 908-915.

Domurath, A. and Patzelt, H. (2016), “Entrepreneurs' Assessments of Early International Entry: The Role of Foreign Social Ties, Venture Absorptive Capacity, and Generalized Trust in Others". Entrepreneurship Theory and Practice, Vol. 40 No. 5, pp. 1149-1177.

Döring, T. and Schnellenbach, J. (2006), "What do we know about geographical knowledge spillovers and regional growth?: A survey of the literature“, Regional Studies, Vol. 40 No. 3, pp. 375-395.

EC (2003), "What is an SME?", available at: http://ec.europa.eu/growth/smes/businessfriendly-environment/sme-definition_en (accessed 12 January 2019). 
EC (2013) Entrepreneurship 2020 Action Plan. Available at: http://eurlex.europa.eu/LexUriServ/LexUriServ.do?uri=COM:2012:0795:FIN:en:PDF

EC (2014a) Supporting the Internationalisation of SMEs. Available at: http://s3platform.jrc.ec.europa.eu/documents/20182/84453/Supporting_Internat_SMEs.pdf/f3 6577c4-53fc-4f44-a02a-d8f5e295158f

EC (2014b) Research and Innovation Performance in the EU - Innovation Union progress at country level. Available at: http://ec.europa.eu/research/innovation-union/pdf/state-of-theunion/2014/iuc_progress_report_2014.pdf\#view=fit\&pagemode=none

EC SBA (2016) "SBA Fact Sheet Germany". Available at: file://C:/Documents\%20and\%20Settings/login/My\%20Documents/Downloads/Germany\%20 -\%202016\%20SBA\%20Fact\%20Sheet.pdf

Eerme, T. and Nummela, N. (2019), "Capitalising on knowledge from big science centres for internationalisation”, International Marketing Review, Vo. 36 No. 1, pp. 108-130.

Ellis, P.D. (2011), "Social ties and international entrepreneurship: Opportunities and constraints affecting firm internationalization", Journal of International Business Studies Vol. 42 No. 1, pp. 99-127.

Elwert, F. (2013). Graphical causal models. In S. L. Morgan (Ed.), Handbook of Causal Analysis for Social Research (pp. 245-273). Dordrecht Heidelberg New York London: Springer.

Eriksson, K. and Chetty, S. (2003), "The Effect of Experience and Absorptive Capacity on Foreign Market Knowledge”, International Business Review, Vol. 12 No. 6, pp. 673-695.

Etemad, H. (2016), "International entrepreneurship as a young field of scholarly inquiry and its relationship with the knowledge network of five disciplines", Journal of International Entrepreneurship, Vol. 14 No. 2, pp. 157-167.

Evers, T. and O'Gorman, C. (2011), "Improvised internationalization in new ventures: The role of prior knowledge and networks", Entrepreneurship and Regional Development, Vol. 23, No. 7-8, pp. 549-574.

Federal Ministry of Education and Research. (2014), "The new High-Tech Strategy Innovations for Germany". Available at: https://www.bmbf.de/pub/HTS_Broschuere_eng.pdf

Ferreras-Mendez, J., Fernandez-Mesa, A. and Alegre, J. (2019), "Export performance in SMEs: The importance of External Knowledge Search Strategies and Absorptive Capacity", Management International Review, Vol. 59, pp.413-437.

Fernhaber, S., McDougall-Covin, P. and Shepherd, D. (2009), "International Entrepreneurship: Leveraging Internal and External Sources”, Strategic Entrepreneurship Journal, Vol. 3, pp. 297-320. 
Filatotchev, I., Liu, X., Lu, J. and Wright, M. (2011), "Knowledge spillovers through human mobility across national borders: Evidence from Zhongguancun Science Park in China", Research Policy, Vol. 40, No. 3, pp. 453-462.

Fletcher, M. (2009), "Learning processes in the development of absorptive capacity of internationalising SMEs. In. Jones, M.V., Dimitratos, P., Fletcher, M. and Young, S. (eds.) Internationalization, Entrepreneurship and The Smaller Firm: Evidence From Around The World. Edward Elgar: Cheltenham, pp. 73-90.

Fletcher, M. and Harris, S. (2012), "Knowledge-acquisition for the internationalization of the smaller firm: content and sources", International Business Review, Vol. 21, No. 4, pp. 631647.

Flor, M.L., Cooper, S.Y. and Oltra, M.J. (2018), "External knowledge search, absorptive capacity and radical innovation in high-technology firms", European Management Journal, Vol. 36 No. 2, pp. 183-194.

Florin, J., Lubatkin, M.H. and Schulze, W.S. (2003), "A Social Capital Model of High-Growth Ventures”, Academy of Management Journal, Vol. 46 No. 3, pp. 374-384.

Garcia-Garcia, R., Garcia-Canal, E. and Guillen, M.F. (2017), "Rapid internationalisation and long-term performance: The knowledge link", Journal of World Business, Vol. 52 No. 1, pp. 97-110.

Garcia-Morales, V., Bolivar-Ramos, M. and Martin-Rojas, R. (2014), "Technological variables and absorptive capacity's influence on performance through corporate entrepreneurship", Journal of Business Research, Vol. 67, pp. 1468-1477.

Gassman, O. and Keup, M. (2007), "The competitive advantage of early and rapidly internationalising SMEs in the biotechnology industry: A knowledge-based view", Journal of World Business, Vol. 42 No. 3, pp. 350-366.

Granovetter, M.S. (1973), "The strength of weak ties", American Journal of Sociology, Vol. 78, pp. 1360-1380.

Hair, J.F., Anderson, R., Tatham, R. and Black, W. (2006), Multivariate Data Analysis, $6^{\text {th }}$ ed., Pearson Prentice Hall, Upper Saddle River, NJ.

Halilem, N., Bertrand, C., Cloutier, J., Landry, R. and Amara, N. (2012) "The knowledge value chain as an SME innovation policy instrument framework: an analytical exploration of SMEs public innovation support in OECD countries", International Journal of Technology Management, Vol. 58, No. 3-4, pp. 236-660.

Hanell, S., Nordman, E.R., Tolstoy, D. and Sharma, D.D. (2018), "Pursuing Innovation: An Investigation of the Foreign Business Relationships of Swedish SMEs", British Journal of Management, Vol. 29 No. 4, pp. 1-18.

Harrison, D.A., McLaughlin, M.E. and Coalter, T.M. (1996), "Context, cognition, and common method variance: Psychometric and verbal protocol evidence“, Organizational Behavior and Human Decision Processes, Vol. 68 No. 3, pp. 246-261. 
Henke, J.W.J. and Zhang, C. (2010), "Increasing supplier-driven innovation", Sloan Management Review, Vol. 51 No. 2, pp. 41-46.

Hessels, J. (2008), "Overcoming Resource Constraints Through Internationalization? An Empirical Analysis of European SMEs", Babson College Entrepreneurship Research Conference (BCERC); Frontiers of Entrepreneurship Research 2008. Available at SSRN: https://ssrn.com/abstract=1348183.

Hollender, L., Zapkau, F.B. and Schwens, C. (2017), "SME foreign market entry mode choice and foreign venture performance: The moderating effect of international experience and product adaptation“, International Business Review, Vol. 26 No. 2, pp. 250-263.

Hughes, A. and Kitson, M. (2010), Cambridge Centre for Business Research Survey of Knowledge Exchange Activity by United Kingdom Academics, 2005-2009, UK Data Service. SN: 6462, available at: http://doi.org/10.5255/UKDA-SN-6462-1.

Ibeh, K., Crick, D. and Etemad, H. (2019) "International marketing knowledge and international entrepreneurship in the contemporary multi-speed global economy", International Marketing Review, Vol. 36, No. 1, pp. 2-5.

Jean, R.-J.B., Sinkovics, R.R. and Kim, D. (2016), “Antecedents and Outcomes of Supplier Innovativeness in International Customer-Supplier Relationships: The Role of Knowledge Distance“, Management International Review, Vol. 57 No. 1, pp. 121-151.

Jones, M.V. (2001), "First steps in internationalisation: Concepts and evidence from a sample of small high-technology firms“, Journal of International Management, Vol. 7 No. 3, pp. 191210 .

Jones, M.V., Coviello, N. and Tang, Y.K. (2011), "International Entrepreneurship research (1989-2009): A domain ontology and thematic analysis", Journal of Business Venturing, Vol. 26 No. 6, pp. 632-659.

Jonsson, S. and Lindbergh, J. (2010), "The Impact of Institutional Impediments and Information and Knowledge Exchange on SMEs' Investments in International Business Relationships", International Business Review, Vol. 19 No. 6, pp. 548-561.

Kang, M-P., Mahoney, J.T. and Tan, D. (2009), "Why firms make unilateral investments specific to other firms: the case of OEM suppliers", Strategic Management Journal, Vol. 30 No. 2, pp. 117-135.

Kim, B., Kim, E. and Foss, N.J. (2016), "Balancing absorptive capacity and inbound open innovation for sustained innovative performance: An attention-based view", European Management Journal, Vol. 34 No. 1, pp. 80-90.

Kollmann, M., Cantwell, J., Hannigan, T., Mudambi, R. and Song, J. (2016), "Knowledge connectivity: An agenda for innovation research in international business", Journal of International Business Studies, Vol. 47 No. 3, pp. 255-262. 
Kuivalainen, O., Saaranketo, S. and Puumalainen, K. (2012), "Start-up patterns of internationalisation: A framework and its application in the context of knowledge-intensive SMEs", European Management Journal, Vol. 30 No. 4, pp. 372-385.

Lane, P.J. and Lubatkin, M. (1998), "Relative absorptive capacity and interorganizational learning', Strategic Management Journal, Vol. 19 No. 5, pp. 461-477.

Lane, P. J., Koka, B.R. and Pathak, S. (2006), "The reification of absorptive capacity: A critical review and rejuvenation of the construct", Academy of Management Review, Vol. 31 No. 4, pp. 833-863.

Laufs, K. and Schwens, C. (2014), "Foreign market entry mode choice of small and mediumsized enterprises: A systematic review and future research agenda“, International Business Review, Vol. 23 No. 6, pp. 1109-1126.

Lasagni, A. (2012), "How Can External Relationships Enhance Innovation in SMEs? New Evidence for Europe”, Journal of Small Business Management, Vol. 50 No. 2, pp. 310-339.

Lazzeretti, L. and Capone, F. (2016), "How proximity matters in innovation networks dynamics along the cluster evolution. A study of the high technology applied to cultural goods", Journal of Business Research, Vol. 69 No. 12, pp. 5855-5865.

Lee, C., Lee, K. and Pennings, M. (2001), "Internal Capabilities, External Networks and Performance: A Study on Technology-Based Ventures", Strategic Management Journal, Vol. 22, pp. 615-640.

Li, L., Li, D. and Shi, W. (2011), "Internationalization, internalization and the performance of US biopharmaceutical SMEs", Multinational Business Review, Vol. 19 No. 1, pp. 65-93.

Liebeskind, J.P., Oliver, A., Zucker, L. and Brewer, M. (1996), "Social Networks, Learning, and Flexibility: Sourcing Scientific Knowledge in New Biotechnology Firms", Organization Science, Vol. 7 No. 4, pp. 359-467.

Limaj, E. and Bernroider, E.W.N. (2019), "The roles of absorptive capacity and cultural balance for exploratory and exploitative innovation in SMEs", Journal of Business Research, Vol 94 No. 1, pp. 137-153.

Lindell, M.K. and Whitney, D.J. (2001), "Accounting for common method variance in crosssectional research designs“, Journal of Applied Psychology, Vol. 86 No. 1, pp. 114-121.

Lindstrand, A. and Melén Hånell, S. (2017), "International and market-specific social capital effects on international opportunity exploitation in the internationalization process", Journal of World Business, Vol. 52 No. 5, pp. 653-663.

Lindstrand, A., Hanell, S. and Nordman, E.R. (2011), "Turning social capital into business: A study of the internationalization of biotech SMEs“, International Business Review, Vol. 20 No. 2, pp. 194-212. 
Mahnke, V., Pedersen, T. and Venzin, M. (2005), "The impact of knowledge management on MNC subsidiary performance: The role of absorptive capacity", Management International Review, Vol. 45 No. 2, pp. 101-119.

Marcone, M. (2012), "SMEs and the internationalisation of R \& D activities: Knowledge transfer flows between firms", European Journal of International Management, Vol. 6 No. 2, pp. 133-153.

Mattes, J. (2012), "Dimensions of Proximity and Knowledge Bases: Innovation between Spatial and Non-Spatial Factors“, Regional Studies, Vol. 46 No. 8, pp.1085-1099.

Maurer, I. and Ebers, M. (2006). "Dynamics of Social Capital and Their Performance Implications: Lessons from Biotechnology Start-ups", Administrative Science Quarterly, Vol. 51 No. 2, pp. 262-292.

McDougall-Covin, P., Jones, M.V. and Serapio, M.G. (2014), "High-Potential Concepts, Phenomena, and Theories for the Advancement of International Entrepreneurship Research", Entrepreneurship Theory and Practice, Vol. 38 No. 1, pp. 1-10.

Miguelez, E. and Moreno, R. (2015), "Knowledge flows and the absorptive capacity of regions", Research Policy, Vol. 44, pp. 833-848.

Nonaka, I. and Takeuchi, H. (1995). The knowledge creating company. Oxford, New York: Oxford University Press.

Nordman, E. and Melen, S. (2008), "The impact of different kinds of knowledge for the internationalization process of Born Globals in biotech business", Journal of World Business, Vol. 43 No. 2, pp. 171-185.

Organisation for Economic Cooperation and Development OECD (2015), "Innovation Strategy 2015 An Agenda For Policy Action", available at: https://www.oecd.org/sti/OECD-InnovationStrategy-2015-CMIN2015-7.pdf

Oehme, M. and Bort, S. (2015), "SME internationalization modes in the German biotechnology industry: The influence of imitation, network position, and international experience“, Journal of International Business Studies, Vol. 46 No. 6, pp. 629-655.

Ojala, A. (2009), "Internationalisation of knowledge-intensive SMEs: The role of network relationships in the entry of a psychically distant market", International Business Review, Vol. 18 No. 1 , pp. 50-59.

Oviatt, B. and McDougall, P. (2005), "Defining International Entrepreneurship and Modeling the Speed of internationalisation", Entrepreneurship Theory and Practice, Vol. 29 No. 5, pp. 537-553.

Park, S., LiPuma, J. and Prange, C. (2015), "VC and entrepreneur knowledge of new venture internationalisation: A review of knowledge components", International Small Business Journal, Vol. 33 No.8, pp. 1-28. 
Partanen, J., Moller, K., Westerlund, M., Rajala, R. and Rajala, A. (2008), "Social capital in the growth of science-and-technology-based SMEs", Industrial Marketing Management, Vol. 37 No. 5, pp. 513-522.

Patterson, W. and Ambrosini, V. (2015), "Configuring absorptive capacity as a key process for research intensive firms“, Technovation, Vol. 36/37, pp. 77-89.

Patton, D. (2014), "Realizing Potential: The Impact of Business Incubation upon the Absorptive Capacity of New Technology Based Firms", International Small Business Journal, Vol. 32 No. 8, pp. 897-917.

Podsakoff, P.M. and Organ, D.W. (1986), "Self-reports in organizational research: Problems and prospects“, Journal of Management, Vol. 12 No. 4, pp. 531-544.

Podsakoff, P.M., MacKenzie, S.B., Lee, J. and Podsakoff, N.P. (2003), "Common Method Biases in Behavioral Research: A Critical Review of the Literature and Recommended Remedies", Journal of Applied Psychology, Vol. 88 No. 5, pp. 879-903.

Prashantham, S. (2015), Born Globals, Networks, and the Large Multinational Enterprise: Insights from Bangalore and Beyond. New York, NY: Routledge.

Prashantham, S. and Young, S. (2011), "Post-entry speed of international new ventures", Entrepreneurship Theory and Practice, Vol. 35 No. 2, pp. 275-292.

Presutti, M. Boari, C. and Fratocchi, L. (2007), "Knowledge acquisition and the foreign development of high-tech start-ups: A social capital approach", International Business Review, Vol. 16 No. 1, pp. 23-46.

Presutti, M., Boari, C. and Fratocchi, L. (2016), "The evolution of inter-organisational social capital with foreign customers: Its direct and interactive effects on SMEs' foreign performance", Journal of World Business, Vol. 51 No. 5, pp. 760-773.

Raymond, L., Bergeron, F., Croteau, A.M. and St.Pierre, J. (2015), "Developing absorptive capacity through e-business: The case of International SMEs", Journal of Small Business Management, Vol. 53 Issue. S1, pp. 75-94.

Reuber, A.R. and Fischer, E. (2011), "International entrepreneurship in internet enabled markets", Journal of Business Venturing, Vol. 26 No. 6, pp. 660-679.

Reuber, A.R., Dimitratos, P. and Kuivalainen, O. (2017), "Beyond categorization: New directions for theory development about entrepreneurial internationalization", Journal of International Business Studies, Vol. 48 No. 4, pp. 411-422.

Roberts, N., Galluch, P.S., Dinger, M. and Grover, V. (2012), "Absorptive capacity and information systems research: Review, synthesis, and directions for future research", MIS Quarterly, Vol. 36 No. 2, pp. 625-648.

Saarenketo, S., Puumalainen, K., Kylaheiko, K. and Kuivalainen, O. (2008), "Linking knowledge and internationalisation in small and medium-sized enterprises in the ICT sector", Technovation, Vol. 28 No. 9, pp. 591-601. 
Saemundsson, R. and Candi, M. (2017), "Absorptive capacity and the identification of opportunities in new technology-based firms", Technovation, Vol. 64-65, pp. 43-49.

Sandberg, S. (2014) "Experiential knowledge antecedent of the SME network mode configuration in emerging market business networks", International Business Review, Vol. 23 No. 1, pp. 20-29.

Schwens, C. and Kabst, R. (2010), "Internationalization of young technology firms: A complementary perspective on antecedents of foreign market familiarity", International Business Review, Vol. 20 No. 1, pp. 60-74.

Schwens, C., Eiche, J. and Kabst, R. (2011), "The moderating impact of informal institutional distance and formal institutional risk on SME entry mode choice“, Journal of Management Studies, Vol. 48 No. 2, pp. 330-351.

Schwens, C., Zapkau, F., Bierwerth, W., Isidor, R., Knight, G. and Kabst, R. (2018), "International Entrepreneurship: A Meta-Analysis on the Internationalization and Performance Relationship”, Entrepreneurship Theory and Practice, https://doi.org/10.1111/etap.12280

Shane, S. (2009), "Why encouraging more people to become entrepreneurs is bad public policy”, Small Business Economics, Vol. 33, pp. 141-149.

Steinmo, M. and Rasmussen, E. (2016), "How firms collaborate with public research organizations: The evolution of proximity dimensions in successful innovation projects", Journal of Business Research, Vol. 69 No. 3, pp. 1250-1259.

Stoian, M., Dimitratos, P. and Plakoyiannaki, E. (2019), "SME internationalisation beyond exporting: A knowledge-based perspective across managers and advisors", Journal of World Business, Vol. 53 No. 5, pp. 786-779.

Storper, M. (1997), “The Regional World: Territorial Development in a Global Economy, Guilford Press, New York, NY.

Studenmund, A. (2001), "Using Econometrics: A Practical Guide”, Addison-Wesley, Boston, MA.

Srivastava, M., Gnyawali, D. and Hatfield, D. (2015), "Behavioural implications of absorptive capacity: The role of technological effort and technological capability in leveraging alliance network technological resources", Technological Forecasting and Social Change, Vol. 92, pp. 346-358.

Verbeke, A., Zargarzadeh, M.A. and Osiyevskyy, O. (2014), "Internalization theory, entrepreneurship and international new ventures", Multinational Business Review, Vol. 22 No. 3, pp. 246-269.

Villar, C., Alegre, J. and Pla-Barber, J. (2014), "Exploring the role of knowledge management practices on exports: A dynamic capabilities view", International Business Review, Vol. 23 No. 1, pp. 38-44. 
Volberda, H.W., Foss, N.J. and Lyles, M.A. (2010), "Absorbing the Concept of Absorptive Capacity: How to Realize Its Potential in the Organization Field", Organization Science, Vol. 21 No. 4, pp. 931-951.

Williams, R. (2016), "Understanding and Interpreting Generalized Ordered Logit Models”, Journal of Mathematical Sociology, Vol. 40 No. 1, pp. 7-20.

Wooldridge, J. M. (2010), "Econometric Analysis of Cross Section and Panel Data", MIT Press, Cambridge, MA.

Wright, M., Westhead, P. and Ucbasaran, D. (2007), "Internationalization of small and medium-sized enterprises (SMEs) and international entrepreneurship: A critique and policy implications", Regional Studies Vol. 41 No. 7, pp. 1013-1029.

Xia, T. and Roper, S. (2016), "Unpacking Open Innovation: Absorptive Capacity, Exploratory and Exploitative Openness, and the Growth of Entrepreneurial Biopharmaceutical Firms", Journal of Small Business Management, Vol. 54 No. 3, pp. 931-952.

Yip, G.S., Biscarri, J.G. and Monti, J.A. (2000), "The role of the internationalization process in the performance of newly internationalizing firms", Journal of International Marketing, Vol. 8 No. 3 , pp. $10-35$.

Yli-Renko, H., Autio, E. and Tontti, V. (2002), "Social capital, knowledge, and the international growth of technology-based new firms", International Business Review, Vol.11 No. 3, pp. 279-304.

Zahra, S.A. and George, G. (2002), "Absorptive Capacity: A Review, Reconceptualization, and Extension“, Academy of Management Review, Vol. 27 No. 2, pp. 185-203.

Zahra, S., Ucbasaran, D. and Newey, L. (2009), "Social knowledge and SMEs innovative gains from internationalisation", European Management Review, Vol. 6 No. 2, pp. 81-93.

Zander, I., McDougall-Covin, P. and Rose, E.L. (2015), "Born globals and international business: Evolution of a field of research", Journal of International Business Studies, Vol. 46 No. 1, pp. 27-35.

Zerwas, D. (2014), "Organizational culture and absorptive capacity - the meaning for SMEs", Springer Gabler, Koblenz-Landau.

Zimmerman, M.A., Barsky, D. and Brouthers, K.D. (2009), "Networks, SMEs, and International Diversification", Multinational Business Review, Vol. 17 No. 4, pp.143-162.

Zhu, H., Hitt, M.A. and Tihanyi, L. (2006), "The internationalization of SMEs in emerging economies: institutional, embeddedness and absorptive capacities “, Journal of Small Business Strategy, Vol. 17 No. 2, pp. 1-26. 
Table 1 Variables and measurement

Variable Conceptual definition Measurement $\quad$ Author(s)

Innovative foreign knowledge External knowledge is additive and facilitates new innovations or substantial improvements

Innovative firms

Innovative suppliers

Universities \& scientific institutions

Absorptive capacity

Age

Size

Industry
Social interaction with firms in geographic location

Social interaction with suppliers in geographic location

Social interaction with universities in geographic location

A firm's ability to recognise the importance of acquiring and understanding new knowledge and applying it to commercial ends

Number of years since establishment

Headcount of full-time employees

Industry the firm operates in
Agreement to the statement 'The knowledge sourced abroad is important for the development of products and patents: 7 point Likert scale. Transformed ${ }^{\mathrm{a}}$ to

binary variable value 0 for 1-4 and value 1 for 5-7.

Indication of the importance of proximity to innovative host country firms: 7 point Likert scale

Indication of the importance of proximity to innovative host country suppliers: 7 point Likert scale

Indication of the importance of proximity to host country universities \& scientific institutions: 7 point Likert scale

Two item construct. Agreement to the two statements 'We can easily acquire the knowledge accessed abroad' and 'We perfectly understand the knowledge accessed abroad': 7 point Likert scale. Cronbach Alpha 0.815

0-5 years; 6-10 years; $>11$ years
Adapted from: Aalbers et al, 2014

Adopted from: Hughes and Kitson, 2010; Ambos, 2005

Adopted from: Hughes and Kitson, 2010; Ambos, 2005; Lindstrand and Melen Hanell, 2017

Adopted from: Hughes and Kitson, 2010; Ambos, 2005; Audretsch,1998

Adopted from: Fletcher, 2009; Mahnke et al, 2005

Adopted from: Huggins et al, 2015

Adopted from: EC, 2003

Micro (1-9 employees); Small (10-49 employees) Medium (50-250 employees)

Firms industry classification: $0=$ biotechnology; $1=$ nanotechnology

Adopted from: Schwens et al, 2011

${ }^{a}$ We transformed the scores by adopting a binary classification scheme (based on Arvanitis and Hollenstein, 2011; Lasagni 2012; Hessels, 2008) to achieve a higher variability and to balance out issues related to the minimum sufficiency requirements for number of observations in each scale 
Table 2 Descriptive statistics and correlation matrix

\begin{tabular}{lccccccccc}
\hline & Mean & $S D$ & 1 & 2 & 3 & 4 & 5 & 6 & 7 \\
\hline (1) Innovative foreign & 0.63 & 1.58 & & & & & & & \\
$\quad$ knowledge & 19.97 & 15.89 & -.027 & & & & & & \\
(2) Age & 62.42 & 64.62 & -.086 & $.37^{* * *}$ & & & & & \\
(3) Size & 0.67 & 0.47 & -.082 & .037 & -.007 & & & \\
(4) Industry & 4.61 & 1.76 & $.339^{* * *}$ & .160 & .026 & -.022 & & & \\
(5) Innovative firms & 3.59 & 1.83 & $.239^{* *}$ & .113 & .035 & .083 & $.301^{* * *}$ & \\
(6) Innovative suppliers & 4.08 & 1.88 & $.187^{* *}$ & -.002 & -.005 & -.157 & $.433^{* * *}$ & .103 \\
(7) Universities \& scientific & & & & & & & & \\
$\quad$ institutions & 5.02 & 1.31 & $.246^{* *}$ & .157 & .067 & -.011 & $.238^{* *}$ & $.292^{* * *}$ & .134 \\
(8) Absorptive capacity & & & & & & & &
\end{tabular}




\begin{tabular}{|c|c|c|c|}
\hline & Model 1 & Model 2 & Full model \\
\hline \multicolumn{4}{|l|}{ Controls } \\
\hline \multicolumn{4}{|l|}{ Firm age (ref: 0-5 years) } \\
\hline Age 6-10 & $1.150(0.430)$ & $1.032(0.379)$ & $1.127(0.454)$ \\
\hline Age $11+$ & $-0.788(0.259)$ & $-0.922(0.284)$ & $0.729(0.249)$ \\
\hline \multicolumn{4}{|l|}{ Firm size (ref: micro) } \\
\hline Small & $1.354(0.407)$ & $1.383(0.389)$ & $1.379(0.439)$ \\
\hline Medium & $-0.736(0.230)$ & $-0.704(0.199)$ & $-0.713(0.225)$ \\
\hline Industry (ref: biotech) & $-0.851(0.182)$ & $-0.864(0.179)$ & $-0.840(0.186)$ \\
\hline \multicolumn{4}{|l|}{ Weak Network Ties } \\
\hline Innovative firms & $1.459(0.186)^{* * *}$ & & $1.398(0.181)^{* * *}$ \\
\hline Innovative suppliers & $1.244(0.138)^{* *}$ & & $1.248(0.145)^{*}$ \\
\hline $\begin{array}{l}\text { Universities and scientific } \\
\text { institutions }\end{array}$ & $1.042(0.121)$ & & $1.010(0.122)$ \\
\hline Absorptive capacity & & $1.544(0.230)^{* * *}$ & $1.346(0.211)^{* *}$ \\
\hline Constant & $0.152(0.102)^{* * *}$ & $-0.217(0.160)^{* *}$ & $-0.047(0.042)^{* *}$ \\
\hline $\mathrm{AIC}$ & 1.241 & 1.318 & 1.213 \\
\hline $\mathrm{BIC}$ & -672.770 & -670.517 & -673.536 \\
\hline No of obs. & 144 & 144 & 144 \\
\hline
\end{tabular}

